\title{
The Sale Of South African Businesses: Navigating Through The Tax Minefield
}

Luan Fouche, Mcom Taxation student, University of Pretoria, South Africa Madeleine Stiglingh, Professor, University of Pretoria, South Africa

\begin{abstract}
The way in which a business manages tax risk may affect both the financial performance and the reputation of the business. The purpose of this article is to assist decision makers and advisors in the tax risk management process by providing a practical tool to assist them in the identification of the tax risks associated with the sale of a business. This risk identification tool will enable the contracting parties to embark on a proactive risk assessment process with the ultimate goal of planning the transaction in a tax efficient manner and successfully navigating the tax minefield that is inherent in the sale of a business.
\end{abstract}

Keywords: Business Combinations; Tax Risk Assessment; Sale of a Business

\section{INTRODUCTION}

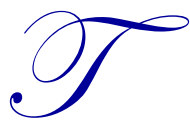

he economic potential of the sale of a business may easily be weighed down by the hidden tax dangers associated with such a transaction. Olivier (2007) fittingly describes the sale of a business as a tax minefield for both the seller and the purchaser. Company boards and responsible tax advisors alike have realised that a meticulous review of the tax consequences of the sale of a business is essential in order to address the inherent tax risks associated with such a transaction (Rudnicki 2010).

This recognition has been reinforced by a recent global merger and acquisition tax survey which found that there is an increased focus on the tax consequences of mergers and acquisitions on a global scale. The survey ascribes this in part to the increased scrutiny by tax authorities of the deal structure with the aim of reducing fiscal debt and also to an increased vigilance on the part of company boards to ensure that the expected value of the transaction is realised (Ernst \& Young 2011).

External growth through mergers and acquisitions will continue to be a lucrative option for multinational corporations (Botha 2004). The first nine months of 2011 saw a worldwide increase in the appetite for merger and acquisition activity with a 22 percent increase in the global merger and acquisition deal value over the comparable 2010 period and this despite continuing economic uncertainty and concerns about a double dip-recession (Thomson Reuters 2011).

Emerging markets, including South Africa, are increasingly becoming the focus of corporate mergers and acquisitions and, in fact, accounted for nearly one-quarter of all merger and acquisition activity during the first three quarters of 2011 (Thomson Reuters 2011). Merger and acquisition transactions in emerging markets offer multinational corporations the opportunity to expand into new markets and to increase the efficiency of their supply chains (Ernst \& Young 2011). However, the potential risk of the transaction should be weighed against the rewards, with corporations investing in emerging markets often being confronted with unfamiliar legal and regulatory challenges of which tax risk is the most significant (Ernst \& Young 2011).

The OECD (2009) defines tax risk as the uncertainty associated with the interpretation of tax law in relation to particular transactions. Molyneux and Du Plessis (2007) similarly describe tax risk as tax uncertainties, but as uncertainties that may have adverse consequences. These adverse consequences are not limited to monetary outflows in the form of tax, interest and penalties only, but may further manifest in damage to the organisation's 
reputation and also potentially undermine the presupposition of good corporate governance by the board of directors.

In some countries the revenue authorities have been driving tax risk management strategies. In Australia, for example, the tax office introduced the Annual Compliance Agreement, in terms of which the chief executive officer is required to present a written assurance that the company is meeting the taxation office's corporate governance guidelines (ATO 2006). The importance of measuring and managing tax risk in any taxpaying corporation has been further underpinned by the introduction of SOX 404 (Sarbanes-Oxley Act of 2002 in the USA, s 404) and now by FIN 48 (Financial Accounting Standards Board Interpretation No. 48, "Accounting for Uncertainty for Income Taxes"), issued by the Financial Accounting Standards Board in the United States of America. The OECD (2009) and Erasmus (2007) agree that both these developments emphasise the importance of transparent corporate governance. Both FIN 48 and SOX 404 are relevant not only to multinationals based in the United States of America but they may also apply to the subsidiaries of foreign-based, large business in the United States of America and other entities not incorporated in the United States of America but which are registered with the Securities and Exchange Commission (OECD 2009).

The Sarbanes-Oxley rules require detailed documentation of the design and operational effectiveness of the internal controls to be put in place, including documentation of the tax risk management policies and controls (Elgood, Paroissien \& Quimby 2006). In 1992, the Committee of Sponsoring Organisations of the Treadway Commission (COSO) published what is referred to as the COSO framework. The COSO framework is the most widely recognised international standard for an integrated framework of internal control (COSO 1992). In view of the fact that the COSO framework is the leading model for internal control and is being used on a global basis, it would appear that it is an appropriate model to consider for the purposes of tax risk management (COSO 2010; OECD 2009; Elgood et al. 2006).

The current COSO framework sets out interrelated components in an integrated system of internal control that applies to organisations of all types and sizes and, hence, should apply equally to tax risk management (Elgood et al. 2006). One of these interrelated components is risk assessment (COSO 1992). Risk assessment is the awareness and response of the organisation to the different types of tax risk facing the said organisation (COSO 1992). This would include the organisation's processes and procedures for identifying and evaluating the tax risks and also the way in which these risks are managed and mitigated consistently in accordance with the overall objectives of the organisation (Elgood et al. 2006). An effective tax risk management system will proactively seek to identify where tax uncertainty arises (Erasmus 2007; Elgood et al. 2006). The sale of a business results in a transactional risk for the taxpayer as a result of the uncertainty arising from the interpretation of relevant tax law and the use of judgement (Elgood et al. 2006: 4). The first step in the tax risk assessment for this transactional tax risk is to identify the tax risks associated with a sale of the business (Erasmus 2007; Elgood et al. 2006).

Some writers, although not specifically focusing on the identification of tax risks, researched the tax consequences of the sale of a business. The first published study was carried out by Stiglingh and Venter (1999) who explored the tax consequences relating to the assumption of liabilities in part settlement of the purchase consideration during the sale of a business. Botha (2004) later analysed the South African tax implications for a multination corporation investing in South Africa through a merger and acquisition while Olivier (2007) addressed both the tax consequences associated with the allocation of the purchase consideration to the constituent assets and the tax consequences related to specific assets and liabilities included in the sale of a business. Kruger (2010) explored the intricacies pertaining to specific Value Added Tax provisions with the aim of addressing the Value Added Tax implications that arise from the sale of a business between vendors. He further critically analysed the conclusions reached by the Supreme Court of Appeal and the previous decision reached by the Tax Court in the Ackermans v CSARS (441/09) [2010] ZASCA 131 case as it relates to the assumption of liabilities in part settlement of the purchase consideration during the sale of a business. A study conducted by Rudnicki (2010) investigated the tax consequences associated with the allocation of the purchase consideration to the constituent assets, the impact of subsequent changes on the purchase consideration and the tax consequences related to specific assets included in the sale of a business. 
The above mentioned studies indirectly identified a limited number of tax risks as it relates to the tax consequences of the transaction but did not provide a coherent and complete identification of the tax risks associated with the sale of a business.

Identifying the tax risks associated with the transaction during the early stages of the merger and acquisition transaction would minimise the immediate tax transaction costs and allow for greater flexibility in future within in a tax efficient structure (Botha 2004). Tax advisors are, consequently, required to be involved at a much earlier date in the transaction negotiations in order to evaluate both the tax risks and tax planning opportunities with the ultimate goal of realising value and avoiding unwanted tax pitfalls (Ernst \& Young 2011).

The purpose of this article is to assist taxpayers in identifying the tax risks associated with the sale of a business and, as such, the article intends to provide a comprehensive risk identification tool. A proper understanding of the transactional risk involved in the sale of a business would enable the taxpayer to decide on a suitable risk appetite and also assist the taxpayer in managing the tax risk effectively (Elgood et al. 2006). In order to understand the scope of this article it is important to note that, in view of the nature of the uncertainties relating to tax, there is often no one correct answer (Elgood et al. 2006). The study is, thus, limited to the identification of transactional tax risks and will provide limited advice and recommendations as to the most practical way in which to manage and resolve the tax risks identified. Accordingly, the focus of the article is on the identification of tax uncertainties (risks) while the article does not purport to explain all the tax consequences associated with the sale of a business transaction. In addition, in view of the fact that transactions within group structures are granted specific tax relief measures (ss 41 to 47 of the Income Tax Act No. 58 of 1962 ("Income Tax Act") and s 8(25) of the Value Added Tax Act No. 89 of 1991 ("Value Added Tax Act")), this article focuses only on the sale of a business transaction between companies which are not part of the same group of companies. Another important aspect influencing the scope of this article is one of the key considerations in a sale of business, namely, the form that the transaction should take. A sale of business transaction may be structured in a variety of ways while the tax consequences resulting from the sale of a business are directly influenced by the form used for the transaction (Wry 2011). The primary methods in terms of which businesses combine in South Africa include the acquisition of the share capital of one company by another or the acquisition of the business (i.e. the assets and liabilities) of one company by another (Davids \& Yuill 2010). The purchaser would generally prefer to structure the transaction as a purchase and sale of the company's business (Wry 2011). The purchaser may selectively acquire particular assets for inclusion in the sale agreement and the price of the desired parts may well be less than the price of the whole (Botha 2004: 6). This study is limited to the identification of the tax risks associated with the sale of a business and will not address the tax risks related to the sale of equity. Future articles will explore the identification of the tax risks associated with the sale of equity.

In order to realise the objective of the article a consultative inquiry strategy involving two processes was adopted. Firstly, a comprehensive literature review, utilising both a synthesis review and a content analysis, was conducted with the aim of critically evaluating and integrating previous studies with different focuses into a comprehensive and internally consistent whole. The literature study initially concentrated on the information available in the public domain. This included a key word search of recognised economic and management science database platforms such as Proquest, Ebscohost and Google Scholar. In addition, a search for relevant case law was conducted on the LexisNexis database platform. The results showed a limited number of relevant literary and case law resources. The limited number of relevant resources available in the public domain necessitated an investigation into unpublished research from other universities in South Africa. This search for unpublished work was conducted at the eight largest universities in South Africa and resulted in a limited number of new literary resources being discovered. Lastly, a search was conducted on the tax precedents database of one of the leading international audit firms. A key word search was performed and the relevant precedents identified were included in the literature review.

The limited number of authoritative, literary sources necessitated a second research process in the form of personal interviews. Lamb, Lymer, Freedman and James (2005) advocate the use of an interdisciplinary approach to taxation research that includes the legal, economic and accounting fields, and, thus, a convenience sample comprising authoritative tax specialists from the legal, economic and accounting fields was selected as interviewees. The interviewee from the legal field was a member of senior council of the Pretoria Bar while the representative 
from the economic field was the chief director of legal and tax design at National Treasury. The representatives from the accounting field included two chartered accountants, one a senior partner of one of the big four auditing firms specialising in corporate taxation and the other the director of tax at the South African Institute of Chartered Accountants. In order to ensure the comprehensiveness of the proposed tax risks investigated the interviewees were, firstly, requested to identify the tax risks they perceived to be attached to the sale of a business and, secondly, they were requested to validate the tax risks which had been identified in the literature review.

The departure point in establishing the value of the seller's business is generally the entity's assets, equity and liabilities, as presented in the statement of financial position of the organisation. Engel (2012) is of the opinion that the nature and importance of the statement of financial position make it a useful basis from which to identify tax uncertainties. The following generic statement of financial position will direct the tax risk identification process and also provide the framework in terms of which tax uncertainties will be identified (see table 1 below).

Table 1: Statement of financial position

\begin{tabular}{|c|c|}
\hline Financial statement caption & Paragraph reference in document \\
\hline \multicolumn{2}{|l|}{ Non-current assets } \\
\hline Property, plant and equipment & Refer paragraph 2 \\
\hline Goodwill & Refer paragraph 3 \\
\hline Other intangible assets & Refer paragraph 4 \\
\hline \multicolumn{2}{|l|}{ Current assets } \\
\hline Inventory & Refer paragraph 5 \\
\hline Trade receivables & Refer paragraph 6 \\
\hline \multicolumn{2}{|l|}{ Other current assets } \\
\hline \multicolumn{2}{|l|}{ Cash and cash equivalents } \\
\hline \multicolumn{2}{|l|}{ Equity and liabilities } \\
\hline \multirow{2}{*}{\multicolumn{2}{|c|}{$\begin{array}{l}\text { Share capital } \\
\text { Retained earnings }\end{array}$}} \\
\hline & \\
\hline \multicolumn{2}{|l|}{ Other components of equity } \\
\hline \multicolumn{2}{|l|}{ Non-current liabilities } \\
\hline \multicolumn{2}{|l|}{ Long-term borrowings } \\
\hline \multicolumn{2}{|l|}{ Deferred tax } \\
\hline Long-term provisions & Refer paragraph 7 \\
\hline \multicolumn{2}{|l|}{ Current liabilities } \\
\hline Trade and other payables & Refer paragraph 8 \\
\hline \multicolumn{2}{|l|}{ Short-term borrowings } \\
\hline \multicolumn{2}{|l|}{ Current portion of long-term borrowings } \\
\hline Current tax payable & Refer paragraph 9 \\
\hline Short-term provisions & Refer paragraph 7 \\
\hline
\end{tabular}

Source: Adapted from Wingard, Von Well, Pretorius, Ferreira, Badenhorst and Van der Merwe (2012).

The article will proceed with the discussion of the relevant aspects that were considered in developing the tax risk identification tool (paragraphs 2 to 9). In view of the fact the sale of a business transaction involves both a seller and a purchaser, the relevant aspects identified through the research are presented, firstly, from the seller's perspective and, thereafter, from the perspective of the purchaser. Finally the tax risk identification tool is presented as part of the conclusion in paragraph 10.

\section{PROPERTY, PLANT AND EQUIPMENT}

Property, plant, and equipment is the first financial statement caption that will be evaluated in terms of the tax uncertainty relating to the sale of a business.

A recoupment arises for the seller in terms of section 8(4)(a) of the Income Tax Act where an allowance asset is disposed of for a price in excess of its tax value. The recoupment amount will be included in the taxable income of the seller where the seller has previously claimed capital allowances in respect of any asset sold to the purchaser. The recoupment is calculated as the excess of the sale proceeds over the depreciated tax value of the asset, limited to a maximum of the aggregate amount of the allowances previously claimed for income tax purposes. 
Where the sale proceeds do not exceed the depreciated tax value of the assets disposed of, the seller may, ordinarily, elect a tax deduction on the loss incurred in terms of section 11(o) of the Income Tax Act. No election may, however, be made in terms of section 11(o) in respect of assets disposed to persons who are connected persons in relation to the seller or where the expected life of the asset exceeds 10 years.

The portion of the purchase consideration in excess of the base cost of the asset constitutes a capital gain and is subject to tax on capital gains. The calculation of capital gains and losses will be performed in respect of every separate asset included in the sale of the business, as opposed to an aggregate tax on capital gains calculation for the business as a whole. Where the capital asset was obtained prior to the introduction of tax on capital gains -1 October 2001 - only the gain or loss generated since this date will be subject to tax on capital gains (para 25 of the Eight Schedule to the Income Tax Act).

The purchaser will not be entitled to deduct expenditure of a capital nature in terms of the general deduction formula (s 11(a) of the Income Tax Act). The purchaser will, however, be entitled to claim capital allowances on the qualifying assets acquired as part of the sale of the business (Olivier 2007). The allowances will usually be calculated by the purchaser with reference to the acquisition cost thereof in terms of the sale of business agreement (ss 12C(1), 13(1) and 13quin (1) of the Income Tax Act).

The purchaser will not have any immediate tax on capital gains implications but needs to record the expenditure related to every asset acquired for the purpose of determining the base cost of those assets. The base cost of an asset acquired on or after 1 October 2001 is generally the expenditure actually incurred in acquiring or creating the asset (para 20(1)(a) of the Eight Schedule to the Income Tax Act). Botha (2004) advises that accurate and complete records should be maintained of all expenses incurred during the sale of business transaction since these costs may potentially be included in the base cost of the assets acquired.

\section{GOODWILL}

The second financial statement caption that will be evaluated for tax uncertainty relating to the sale of a business is goodwill.

The seller will usually attribute the balance of the purchase consideration to goodwill. The consideration received in respect of goodwill is, ordinarily, capital in nature and subject to tax on capital gains (Botha, 2004). Botha (2012) is of the opinion that one of the key taxes on capital considerations during the sale of a business will be the determination of the base cost of goodwill.

Business acquisitions are accounted for by the purchaser under the revised International Financial Reporting Standard 3 (IFRS 3). Excluded from the scope of IFRS 3 is "the acquisition of an asset or group of assets that does not constitute a business" (IFRS 3, para 2(b)). One of the key implementation challenges of IFRS 3 involves differentiating between the acquisition of a business and the acquisition of a group of assets (PwC 2011). There are a number of fundamental accounting differences between a business combination and the acquisition of a group of assets and one of the key differences relates to the recognition of goodwill (PwC 2011). IFRS 3 states that the total cost of an asset group which does not constitute a business shall be allocated to the individual, identifiable assets and liabilities on the basis of their relative fair values and, therefore, no goodwill will arise from the transaction (IFRS 3, para 2(b)). There is, consequently, a risk that goodwill may arise from a tax perspective (portion of the purchase consideration not allocated to identifiable assets) but be prohibited for accounting purposes and this would, ultimately, result in different cost allocations for accounting and tax purposes. The recognition of goodwill is, however, not prohibited where the sale of the group of assets constitutes a business as defined in IFRS 3 (IFRS 3, para 32). In addition, a business combination that involves the acquisition of the net assets (including any goodwill) of the seller does not result in a parent subsidiary relationship and IFRS 3 will apply in the purchaser's separate financial statements (Wingard, Von Well, Pretorius, Ferreira, Badenhorst \& Van der Merwe 2012).

Goodwill is measured at acquisition date as the excess of the fair value of the consideration transferred over the net value of the identifiable assets acquired and the liabilities assumed (IFRS 3, para 32). However, the purchaser will not be entitled to any allowances in respect of any portion of the purchase consideration allocated to 
goodwill. Botha (2011), therefore, advises that careful consideration be given to allocating the purchase consideration as far as possible to those tangible assets which qualify for deduction in terms of the Income Tax Act in order to minimise the amount of goodwill recognised as part of the transaction.

\section{OTHER INTANGIBLE ASSETS}

The tax uncertainties related to other intangible assets for both the seller and the purchaser are similar to those relating to property, plant and equipment. Please refer to paragraph 2 for an evaluation of the tax uncertainties related to the property, plant and equipment financial statement caption.

The purchaser will, in addition, not be entitled to any allowances in respect of trademarks acquired after 1 January 2004 in terms of section 11(gC) of the Income Tax Act. Section 11(gC), however, provides for allowances in respect of other intellectual property such as designs, patents and copyrights or assets of a similar nature. Botha (2004) cautions purchasers that registration and license fees may be payable in respect of the acquired assets since the sale of a business results in the legal transfer of each asset.

\section{INVENTORY}

The fourth financial statement caption that will be evaluated for tax uncertainty relating to the sale of a business is inventory.

Section 22(8) of the Income Tax Act deems the seller to have recouped or recovered an amount equal to the market value of the inventory where the inventory is disposed of by a taxpayer other than in the ordinary course of his/her trade for a consideration less than the market value thereof. The term 'other than in the course of his/her trade' is not defined in the Income Tax Act. It is, however, submitted that the sale of inventory as part of the sale of a business may fall within the ambit of this expression (Rudnicki 2010). Consideration should, therefore, be given as to whether the amount attributed to the inventory in the sale of business agreement reflects the market value as contemplated in section 22(8) (Rudnicki 2010).

Rudnicki (2010) is of the opinion that the price agreed between the independent contracting parties as part of a sale of business usually reflects the market price in such circumstances and is indicative of the prevailing price of the inventory. Olivier (2007) advises sellers to dispose of inventory for at least its tax value during the sale of a business since a disposal at below tax value may arouse the suspicion of the South African Revenue Service that excessive amounts were claimed as deductions in the past and this may, in turn, result in a full scale investigation into the transaction. In view of the fact that the acquisition cost of the inventory will be deducted from taxable income by the seller in the year of the sale, only the profit realised on the sale of the inventory will be taxed (ss 11(a) and 22(2) of the Income Tax Act).

Any consideration paid by the purchaser for inventory will be deductible for income tax purposes, subject to the timing provisions contained in section 22 of the Income Tax Act. A mismatch would occur where inventory is disposed of by the seller for less than market value. Under these circumstances the seller would be deemed to dispose of the inventory at market value whereas the purchaser is deemed to have acquired the inventory at cost (s 22(3)(a)(i)). The cost of transporting the stock to a new location and preparing the stock for sale will also be deductible (Wilcocks 2012).

\section{TRADE RECEIVABLES}

The fifth financial statement caption that will be evaluated for tax uncertainty relating to the sale of a business is trade receivables.

The sale of trade receivables may result in an undesirable tax position for both the buyer and the seller where a portion of the receivables so disposed of becomes irrecoverable in a year of assessment subsequent to the year of assessment in which the sale of the business occurred. The debt will no longer be due to the seller if the trade debt is sold. The debt was, furthermore, not included in the income of the purchaser as it was acquired as a capital 
asset. This will result in a position where neither the purchaser nor the seller will be in a position to claim the bad debt under section 11(i) of the Income Tax Act as the requirements of the section were not met. It is, thus, recommended that the seller dispose of trade receivables at tax value with a right to recourse (resolutive condition) in respect of bad debt (Olivier 2007). This approach was confirmed in the SIR v Kempton Furnishers (Pty) Ltd 1974(3) SA 36 (A) case where it was held that the deduction in terms of section 11(i) was still permissible under these circumstances even though the seller had already disposed of the business. This may, however, not be the most suitable alternative for the seller in the absence of future taxable income where the business operations come to a close after the sale of the business assets. Botha (2004) further recommends that a detailed analysis of all trade receivables be performed prior to the sale of the business. All the receivables that may specifically be identified as irrecoverable should not form part of the transferred trade receivables and the seller should write the bad debts off before the business is sold.

No input tax deduction will be allowed when a Value Added Tax vendor transfers trade receivables at face value on a non-recourse basis to the purchaser. However, an adjustment is allowable to the extent that the amount received is less than the face value (s 22(1)(c)(iv)(aa) of the Value Added Tax Act). The seller will similarly be entitled to an input tax deduction, on the assumption that the seller is still a registered Value Added Tax vendor after the sale of the business, where an irrecoverable amount is ceded back to the seller who transferred the trade receivable on a recourse basis to the purchaser (s 22(1)(c)(iv)(bb) of the Value Added Tax Act).

The portion of the sale proceeds attributed to trade receivables constitutes a receipt of a capital nature and will be subject to tax on capital gains where the proceeds exceed the face value of the trade receivables (Olivier 2007).

The purchaser must ensure that a specific amount is allocated to trade receivables in the sale of business agreement in order to establish the base cost of the asset for tax on capital gains purposes. This will enable the purchaser to claim a capital loss in respect of subsequent irrecoverable debts (Olivier 2007). The portion of the debt recovered by the purchaser in excess of the purchase consideration will, similarly, be subject to tax on capital gains (Nel 2012).

The purchaser will be entitled to an input tax deduction on trade receivables transferred on a non-recourse basis and written off as irrecoverable irrespective of the fact that he/she did not originally account for the output tax on the supply (s 22(1A) of the Value Added Tax Act).

\section{LONG-TERM AND SHORT-TERM PROVISIONS}

The evaluation of the tax uncertainty relating to the sale of a business will now move from the asset categories to the liabilities section of the statement of financial position. The assessment of the liabilities section will commence with long-term and short-term provisions.

The allocation of liabilities, both contingent and actual, regularly forms part of the sale of business agreement. It is, however, noteworthy that the attendant tax consequences of the assumption of liabilities is rarely considered in the sale of business agreement (Rudnicki 2010). An international survey on merger and acquisition activity conducted by KPMG during 2006 identified unrecorded liabilities and provisions as the top tax issue facing merger and acquisition participants (KPMG 2006).

The sale of business agreement is normally structured in such a way that the purchaser assumes the liabilities of the seller relating to the business. The assumption by the purchaser of a liability in settlement of the purchase consideration would normally not give rise to adverse tax consequences for the seller where the relevant liability resulted from expenditure which has actually been incurred. A question as to the correct tax treatment in the context of a sale of business transaction, however, arises where the related expense has not been actually incurred as a result of the specific requirements of the Income Tax Act (Kruger 2010).

It was held by the Supreme Court of Appeal in the Ackermans $v$ CSARS (441/09) [2010] ZASCA 131 ("Ackermans") case that the seller does not actually incur expenditure relating to conditional liabilities under a sale 
agreement where the purchase consideration is reflected as a net amount since there is no discharge of an obligation owed by the seller to the purchaser (para 8, page 6). The expenditure is, therefore, not deductible in terms of section 11 (a) read with section 23 (g) of the Income Tax Act.

The Supreme Court of Appeal further decided that it could not be argued that set-off occurred since set-off comes into operation only when two parties are mutually indebted to each other and both debts are liquidated and fully due. The Supreme Court of Appeal held that the criteria were not met in the Ackermans case as the sale of business agreement did not create an obligation due by the seller to the purchaser (para 8, page 6). Kruger (2010) is of the opinion that set-off will apply and that the expenditure will, therefore, be regarded as actually incurred if the sale agreement explicitly provides for the seller to pay an amount in consideration to the purchaser for the contingent liabilities assumed. Kruger (2010) further argues that the expenditure incurred under these circumstances relates to the assumption of the obligation by the seller to pay the purchaser for the assumed liabilities under the sale of business agreement and not the underlying contingent liabilities which remain unconditional and, therefore, not actually incurred.

The Tax Court previously found in ITC 183972 SATC 61 that the expenditure incurred by the seller (if any) was not in the production of income, but rather a payment to induce the purchaser to take over the liabilities (para 31). The Tax Court, however, conceded that the expenditure would have been incurred in the production of the seller's income were it not for the disposal of the business (para 31). Kruger (2010) is of the opinion that expenditure incurred by the taxpayer for the discharge of an obligation is in itself deductible if fulfilment of the obligation would have resulted in a tax deductible expense.

The Tax Court in ITC 183972 SATC 61 moreover found that the expenditure incurred by the seller (if any) would be of a capital nature as the sale of a business would result in a cessation of trade and it could, therefore, not be argued that the expenditure is more closely related to its income earning operations (para 32). Kruger (2010) maintains that the expenditure was incurred in relation to the assumed liabilities by the purchaser which arose during the income earning operations of the seller and does not relate to the sale of the business. It is, therefore, argued that the expenditure incurred is revenue in nature since the expenditure is more closely connected with the income earning operations than the income earning structure of the seller's business.

The Tax Court in ITC 183972 SATC 61 furthermore found that the expenditure incurred by the seller (if any) was not laid out or expended for the purposes of the taxpayer's trade since the transaction was undertaken with the intention of enabling the taxpayer to sell his/her business and to bring the seller's trading activities to an end (para 33). Kruger (2010) is of the opinion that the expenditure relating to the assumed liabilities was incurred while the seller was conducting trade and was, therefore, laid out or expended for the purposes of the taxpayer's trade as contemplated in section 23(g) of the Income Tax Act. According to Stiglingh and Venter (1999), a distinction should be made between obligations that accrue with time, for example, rent and interest, and obligations that were assumed before the discontinuation of the trade but which realise only after the business has ceased, for example, leave pay and product warranty provisions. It is submitted by Stiglingh and Venter (1999) that expenditure relating to an obligation assumed by the taxpayer while conducting a trade will continue to be deductible even if it realises after the discontinuation of the trade.

A further recoupment provision in terms of section $8(4)(\mathrm{m})$ of the Income Tax Act may impact the seller's tax position if the purchaser takes over the seller's liabilities. Section $8(4)(\mathrm{m})$ requires the seller to be relieved of an obligation to make payment for expenditure actually incurred and previously allowed as a tax deduction. Olivier (2007: 607) is of the opinion that the section will not apply where the seller pays an amount to the purchaser for assuming liabilities that was previously claimed as a tax deduction. There is, however, a risk that the section may apply where there is no clear arrangement that consideration was paid or accounted for in taking over the liability, for example, where there is simply a net purchase consideration payable for the business (Olivier 2007).

The assumption of liabilities represents the cost incurred by the purchaser in obtaining the assets. Both section 11(a) of the Income Tax Act and paragraph 20(a) of the Eight Schedule to the Income Tax Act require expenditure to be actually incurred. Provisions and contingent liabilities represent conditional amounts which have not been actually incurred for tax purposes and are, therefore, not deductible in terms of section 11(a) of the Income 
Tax Act and do qualify for inclusion in the base cost of the asset in terms of paragraph 20(a) of the Eight Schedule to the Income Tax Act. However, the incurring of expenses associated with provisions and contingent liabilities may be deferred for an extended period. Rudnicki (2012) is of the opinion that the contracting parties should specifically allocate the portion of the purchase consideration relating to provisions and contingent liabilities to long term assets, for example, goodwill, in an effort to ensure that the incurring of expenses associated with provisions and contingent liabilities is achieved before resale.

The question as to whether the 'reduction' in the purchase consideration or, alternatively, the payment received by the purchaser to assume the liabilities result in an amount to be included in the gross income of the purchaser arises. Stiglingh and Venter (1999) are of the opinion that the 'reduction' in the purchase consideration is not an amount received by or accruing to the purchaser and the amount should, therefore, not be included in the gross income of the purchaser. Stiglingh and Venter (1999) further argue that the 'reduction' in the purchase consideration is not for the benefit of the purchaser, as an obligation is now assumed by the purchaser to pay an amount in future. Stiglingh and Venter (1999), however, caution that an amount could be received by the purchaser for his/her own benefit if the obligation is contingent only at the transaction date and the purchaser is entitled to the difference between the obligation paid and the 'reduction' in the purchase consideration (Stiglingh \& Venter 1999). Stiglingh and Venter (1999) go on to argue that, even if the amount did, in fact, accrue or was received by the purchaser, this amount would be regarded as capital in nature. Stiglingh and Venter (1999) describe the surplus 'payment' (if any) which the purchaser retains after payment of a contingent obligation as an incidental profit. They further argue that it was never the intention of the purchaser to enter a scheme of profit making in paying the obligation and that the profit made by the purchaser does not form part of normal trading activities (i.e. the receipt, if any, is not worked for and unplanned).

There is further uncertainty relating to the future deductibility of the assumed liabilities by the purchaser. The Supreme Court of Appeal and the Counsel representing the Commissioner conceded in the Ackermans case that the purchaser will be entitled to a deduction of the assumed liabilities when they become unconditional (para 9, page 7). This argument is reinforced by proposed law amendments and recent rulings issued by the South African Revenue Service (ss 11F and 24CA of the Draft Taxation Laws Amendment Bill 2011; Binding Class Ruling: BCR 029). Kruger (2010) is of the opinion that this interpretation by the Supreme Court could be disputed on the grounds that the expenditure would not have been incurred in the production of the purchaser's income, the expenditure will be of a capital nature as it relates to the cost of acquiring the income earning structure and the expenditure would not have been incurred for the purposes of the purchaser's trade. Stiglingh and Venter (1999) are also of the opinion that the expenditure is not in the production of income and is, therefore, non-deductible. Botha (2004) agrees with this assessment and argues that the payment of the obligation by the purchaser would normally be an expense of a capital nature since the original reason for assuming the obligation was to acquire the assets and not to fund the income earning operations.

\section{TRADE AND OTHER PAYABLES}

The second financial statement caption included in the liabilities section of the statement of financial position that will be evaluated for tax uncertainty related to the sale of a business is trade and other payables. The unsettled Value Added Tax obligation is usually presented as part of trade and other payables. The sale of a business may, potentially, have a direct and significant influence on the Value Added Tax position of both contracting parties.

The sale of business assets by a registered vendor constitutes the supply of goods for Value Added Tax purposes and, thus, Value Added Tax should be charged at a rate of 14 percent in the absence of any special provisions contained in the Value Added Tax Act (s 7(1)(a) of the Value Added Tax Act). The sale will, however, not be subject to Value Added Tax where the seller is not a registered Value Added Tax vendor or where no input tax credit was previously claimed (s 8(14)(a) of the Value Added Tax Act). Sections 11(1)(e) and 8(25) of the Value Added Tax Act are aimed at addressing the Value Added Tax implications that arise from the sale of a business between vendors. 
Section 11(1)(e) provides for Value Added Tax to be charged at a rate of zero percent when the seller disposes of a qualifying going concern, while section 11(e)(ii) enables the seller to levy Value Added Tax at a rate of zero percent on the full enterprise value where goods or services were applied mainly (more than 50\%) for the purposes of such enterprise. The seller will further be entitled to an additional input tax deduction in terms of section 16(3)(h) on goods and services that were used or applied for purposes other than making taxable supplies and included as part of the supply of the going concern. However, the purchaser will not be entitled to claim an input tax deduction on the supply of the going concern and will, in addition, be responsible for a deemed supply to the extent that the enterprise was acquired by the purchaser for the purpose other than making taxable supplies (s 18A of the Value Added Tax Act). The provisions of section 18A will not apply where the purchaser intends to use the enterprise 95 percent or more for the purposes of making taxable supplies (s 18A of the Value Added Tax Act).

Section 8(25) applies where any goods or services are supplied by a vendor to another vendor and the provisions of section 42 (asset-for-share transactions), section 44 (amalgamation transactions), section 45 (intragroup transactions) or section 47 (liquidation, winding up and deregistration) of the Income Tax Act are complied with. Should the provisions of section 8(25) apply, the seller making the supply of the goods and services comprising the going concern and the purchaser acquiring the going concern are deemed to be one and the same person for the purposes of the supply of the going concern. The supply will, therefore, be ignored for Value Added Tax purposes and deemed to be a non-supply (Kruger 2010).

Section 11(1)(e) requires the parties to be registered as Value Added Tax vendors. Section 8(25), in contrast, does not require the parties to be registered Value Added Tax vendors and merely requires the parties to be vendors. A vendor is defined in section 1 of the Value Added Tax Act as "any person who is or is required to be registered under the Value Added Tax Act". Non registration of one of the contracting parties will place the transaction outside the scope of section 11(1)(e). The parties may, however, rely on section 8(25), since this section merely requires the parties to be vendors for Value Added Tax purposes. Section 8(25), therefore, provides a practical solution to the situation where the Value Added Tax registration of one or both of the parties is delayed beyond the completion date of the transaction (Kruger 2010). The Value Added Tax implications that arise from the sale of a business must be determined with reference to the other provisions of the Value Added Tax Act where the transaction falls outside the ambit of sections 11(1)(e) and 8(25).

An additional output tax arises in terms of section 22(3) of the Value Added Tax Act when a vendor on the invoice basis has deducted input tax in respect of a taxable supply of goods and services and, in addition, did not pay the full consideration for the supply within 12 months from the end of the tax period in which the deduction was claimed. Nel (2012) is of the opinion that, in view of the fact that the responsibility for payment now resides with the purchaser, there is a risk, in terms of section 22(3), that the seller may have to account for additional output tax on the liabilities transferred to the purchaser as part of the sale of business agreement and on which an input deduction was previously claimed. However, Louw (2012) maintains that it may be argued that the full consideration in respect of the supply was made by the seller through the 'reduction' in the purchase consideration. The seller may similarly be responsible for output tax on outstanding balances owing to suppliers not older than 12 months when he ceases to be a vendor as a consequence of the sale of business (s 8(2) of the Value Added Tax Act).

The purchaser is entitled to claim an input tax of 14 percent on the acquisition of the immovable property should the purchaser be registered as a Value Added Tax vendor. The sale of immovable property is further subject to transfer duty. The purchaser (in the case of a legal person) will be subject to transfer duty on a sliding scale rate, depending on the value of the immovable property. The Transfer Duty Act, however, contains an exemption from transfer duty to the extent that the supply is subject to Value Added Tax.

There is further uncertainty relating to the treatment of input tax on expenses associated with the sale of a business. It was held in the Commissioner for SARS v De Beers (503/2011) [2012] ZASCA 103 case that

"... there is a clear distinction between the enterprise with its attendant overhead expenses and the special duties imposed on a company in respect of its shareholders. The duty imposed on a public company that is the target of a takeover is too far removed from the advancement of the Value Added Tax enterprise to justify characterising the services acquired in the discharge of that duty as services acquired for the purposes of making taxable supplies" (para 27, page 13). 
The appellant in this case failed to convince the court that a direct and immediate link existed between the expenses incurred in relation to the takeover and the taxable supplies when considering the nature of the enterprise. There is, consequently, a risk that input tax will be denied on expenses associated with the sale of a business.

\section{CURRENT TAX PAYABLE}

The sale of business transaction gives rise to a number of tax uncertainties that may not be specifically allocated to the previously evaluated financial statement captions, but may, however, ultimately affect the tax payable by the transactional parties. These tax uncertainties relate to future expenditure on contracts (para 9.1), the allocation of the purchase consideration (para 9.2), adjustments to the purchase consideration (para 9.3), the party responsible for the tax for the period between the effective date and the completion date of the agreement (para 9.4), financing of the sale of business transaction (para 9.5) and the cost incurred relating to the sale of business transaction (para 9.6).

\subsection{Future expenditure on contracts}

The Income Tax Act provides for an allowance in respect of future expenditure on contracts in terms of section 24C of the Income Tax Act. Olivier (2007) is of the opinion that the seller will no longer be able to claim a further section $24 \mathrm{C}$ allowance as the seller will be unable to prove that such an amount will be utilised in whole or in part to finance future expenditure which would be incurred by the seller in the performance of his obligations under the contract. Section $24 \mathrm{C}(3)$ further deems the allowance to be income received by or accrued to the taxpayer in the following year of assessment. The seller should, therefore, take cognisance of the fact that the previous section $24 \mathrm{C}$ allowances will be deemed income in the following year of assessment and should evaluate the future tax position of the business, especially where trade has ceased after the sale of the business and limited future income tax deductions are expected.

Olivier (2007) is of the opinion that the purchaser will not be entitled to claim a deduction of the expenditure incurred in fulfilment of the contract obligations taken over as part of the sale of business in the absence of the right to receive the consideration already delivered and the future consideration to be delivered under the contract.

\subsection{Purchase consideration allocation}

It was established in the CIR v Niko 1940 AD 416, 11 SATC 124 case that the purchase consideration for the sale of a business should not merely be expressed as either a lump sum or a net amount, but that it is essential to allocate or apportion the contract price to each constituent asset. This is necessary as the sale of a business will, for income tax purposes, result in the disposal of each identifiable asset (both tangible and intangible) of the seller (Rudnicki 2010). Rudnicki (2010) is of the opinion that the allocation of the purchase consideration on an asset-byasset basis is necessary, irrespective of the fact that the consideration for the business may be more or less than the accounting book value. It is submitted that the parties have unfettered discretion as to the allocation of the purchase consideration to the underlying assets ( $\mathrm{Nel}$ 2012). Where the allocation was, however, performed solely or mainly to avoid the payment of tax, it may become subject to the general anti-tax avoidance provisions of section 80A to 80T of the Income Tax Act. The South African Revenue Service will be entitled to a fair and reasonable allocation of the purchase consideration in the absence of such an allocation in the sale of business agreement and the burden of proof will be on the taxpayer to prove an incorrect allocation by the South African Revenue Service (Olivier 2007).

It was held in the recent Supreme Court of Appeal judgment in Eveready v The Commissioner for the SARS (195/11) [2012] ZASCA 36 that the sale agreement had to be interpreted on the facts as they appeared in the sale agreement (para 10, page 5). The Supreme Court of Appeal disallowed oral evidence as to the meaning of the written agreement. The judgment again confirmed the importance of clearly setting out the allocation of the purchase consideration to the various assets during the sale of a sale of business. As previously stated, the purchaser may selectively acquire assets of the business as opposed to the total inherent history of the target company when the transaction is structured as a sale of the business concerned. It is, therefore, essential that the purchaser identify those assets that are subject to the sale of the business (Botha 2004). 
According to Rudnicki (2012), the purchaser should ensure that each asset is specifically recorded, including those assets not currently reflected in the financial records of the seller. This approach will enable the purchaser to establish a cost base for specific intangible assets, for example, valuable contracts, brand names and trademarks, instead of assuming that the excess over book value is attributable to goodwill. This approach is consistent with the requirements of IFRS 3 which requires the purchaser to recognise, separately from goodwill, all identifiable, intangible assets acquired as part of the sale of a business (IFRS 3, para 10).

The net asset value of the business may further exceed the purchase consideration, thus resulting in a bargain purchase (negative goodwill). Rudnicki (2012) is of the opinion that the sale of business agreement should specifically provide for the allocation of the bargain purchase to assets so as to establish a selling price for the seller and a cost base for the purchaser.

\subsection{Adjustments to purchase consideration}

The sale of business agreement often provides for an adjustment to the purchase consideration through socalled earn out provisions. These provisions usually provide for the determination of a portion of the purchase consideration based on the future financial performance of the business acquired (Rudnicki 2010). The South African Revenue Service may argue that the adjustment to the purchase consideration relating to the earn out portion of the purchase consideration constitutes gross income in the hands of the seller, as opposed to being part of the purchase consideration received on capital account. The risk exists that the amount of the earn out may be regarded as revenue in nature where the payment is structured as an annuity or where the amount is determined with reference to a formula based on future financial performance (Rudnicki 2012). In this regard it was held in Deary v CIR 1920 CPD 541, 32 SATC 92 that, in the absence of a predetermined lump sum, the subsequent recurrent payment of a portion of the profits as consideration for the sale of business retains its revenue nature and is, consequently, included in the taxable income of the seller (para 32).

It was, however, held in IRC $v$ Ramsay 20 TC 79 that the sale of a capital asset for a fixed amount that is payable in instalments remains capital in nature, even though the amount was not received as a lump sum (para 12). It was further held in IRC v Ledgard 21 TC 129 that, where the purchase consideration is fixed, but payable as a percentage of the profits, the seller would not necessarily have a right to the profits, but rather a right to the purchase consideration that will ultimately be settled by profits generated by the business (para 11).

The tax position of the purchaser is less certain and remains untested by the highest courts. According to Rudnicki (2012), strong arguments exist for the deductibility of payments out of profits for the purpose of acquiring capital assets in terms of section 11(a) of the Income Tax Act.

Rudnicki (2010) is of the opinion that the sale of business agreement should deal separately with adjustments to the purchase consideration and allocate the adjustment to an agreed asset (usually goodwill) or as an alternative to all the assets disposed off. The South African Revenue Service may, in the absence of such a provision, use its discretion to allocate the adjusted consideration.

\subsection{Effective date versus completion date of the agreement}

Sale of business agreements typically provide for an effective date of the agreement as well as a completion date. The completion date is typically the date on which all suspensive conditions attaching to the sale of business agreement have been met (Rudnicki 2010). Consideration should be given to who (i.e. purchaser or seller) must account for the accrual of income and expenditure arising from operating the business during this intervening period. Louw (2012) is of the opinion that the income and expenditure arising during the intervening period accrue to the seller until all suspensive conditions have been met. The sale of business agreement should deal separately with and provide for a purchase consideration adjustment so as to account for the accrual of income and expenditure between the effective date and the completion date (Rudnicki 2010).

The contracting parties may, as an alternative, decide to agree inter parties that the risk and reward of ownership in relation to the assets, liabilities, income and expenditure is transferred to the purchaser on the effective 
date (Rudnicki 2010). This approach will result in the purchaser accruing for the income and expenditure during the intervening period and no subsequent purchase price adjustment is, therefore, required. Rudnicki (2010), however, points out that the time of disposal may be deferred beyond the effective date, irrespective of the agreement between the parties if the disposal of the assets is subject to a suspensive condition. Paragraph 13(1)(a)(i) of the Eight Schedule to the Income Tax Act deems the time of disposal of a capital asset subject to suspensive conditions to be the date on which the conditions are fulfilled. Rudnicki (2010) further states that it could be argued that, where the risk and rewards of ownership are settled at the effective date, there are no suspensive conditions attached to the disposal of the assets and any envisaged condition becomes a resolutive condition. Under these circumstances paragraph 13(1)(a)(ii) of the Eight Schedule deems the time of disposal of an asset by means of a agreement which is not subject to a suspensive condition to be the date on which the agreement is concluded.

\subsection{Financing of a sale of business transaction}

According to Botha (2004), there are a number of different ways in which funding may be obtained and payment may be affected during the structuring phase of a merger and acquisition transaction. The different forms of funding available include cash, debt, issuing of shares, convertible securities and contingent payments. Although the form of financing ordinarily involves a balancing of business and tax considerations, tax considerations may, ultimately, dictate the form of financing (Botha 2004).

Botha (2004) maintains that the income tax treatment of interest and dividends plays a critical role in decisions regarding the form of financing to be used for the transaction. Funding by way of interest bearing debt is often preferred over equity funding as a result of the deductibility of interest. Botha (2004) further adds that financing by way of debt will, generally, provide a tax-free means of repatriating funds from the project and will result in a more flexible structure for future capital restructuring and expansion. The purchaser must carry on a trade and also incur the interest in the production of income in order to claim the deemed interest accrual amounts as a deduction for income tax purposes (s 24J(2) of the Income Tax Act).

Interest incurred on debt to finance the acquisition of a business is generally deductible as there is a clear connection between the interest incurred and the income producing activities of the business. The deductibility of the interest will, however, be dependent on the nature of the acquired assets. Interest incurred on acquiring nonproductive assets (i.e. assets that are likely to generate or produce non taxable income or no income) will not be deductible (s $24 \mathrm{~J}(2))$.

\subsection{Cost incurred relating to a sale of business transaction}

A variety of costs will be incurred by both contracting parties during the sale of business transaction. These costs include legal costs, consulting fees and valuation fees relating to the transaction. Botha (2004) is of the opinion that the costs associated with the sale of a business create an enduring benefit as these costs have been incurred in order to establish a capital structure and to acquire capital assets. It, therefore, follows that the costs associated with the transaction are usually capital in nature and not deductible in terms of section 11(a) of the Income Tax Act. The non-deductible expenditure may, however, potentially be included as part of the base cost of the assets for tax on capital gains purposes (para 20 of the Eight Schedule to the Income Tax Act).

\section{SUMMARY AND CONCLUSION}

The way in which a business manages tax risk may affect its financial performance and reputation (Elgood et al. 2006). The purpose of this article is to assist decision makers and advisors in their tax risk management process by providing a practical tool to assist them in the identification of the tax risks associated with the sale of a business (see table 2 below). 
Table 2: Tax risk identification tool

\begin{tabular}{|c|c|}
\hline $\begin{array}{l}\text { Financial statement } \\
\text { caption }\end{array}$ & Tax uncertainty description \\
\hline \multicolumn{2}{|l|}{ Non-current assets } \\
\hline $\begin{array}{l}\text { Property, plant and } \\
\text { equipment }\end{array}$ & $\begin{array}{l}\text { Seller: } \\
\text { - Tax uncertainty relating to the existence and value of the recoupment of previous capital allowances or } \\
\text { scrapping allowances. } \\
\text { - Uncertainty relating to the tax consequences when the purchase price for the asset exceeds the original } \\
\text { cost thereof. } \\
\text { Purchaser: } \\
\text { - Tax uncertainty relating to the determination of the base cost of the acquired assets. }\end{array}$ \\
\hline Goodwill & $\begin{array}{l}\text { Seller and purchaser: } \\
\text { - Tax uncertainty relating to the treatment of goodwill acquired and disposed of as part of a sale of } \\
\text { business. } \\
\text { Inconsistent accounting and tax cost price allocation resulting from the application of International } \\
\text { Financial Reporting Standard 3. }\end{array}$ \\
\hline $\begin{array}{l}\text { Other intangible } \\
\text { assets }\end{array}$ & Tax uncertainties are similar to those pertaining to property, plant and equipment. \\
\hline \multicolumn{2}{|l|}{ Current assets } \\
\hline Inventory & $\begin{array}{l}\text { Seller: } \\
\text { - Tax uncertainty relating to the existence and value of the recoupment of previous deductions related to } \\
\text { the inventory disposed of as part of the sale of business. } \\
\text { Purchaser: } \\
\text { - Tax uncertainty relating to the existence and value of the deduction of inventory acquired as part of the } \\
\text { sale of business. }\end{array}$ \\
\hline Trade receivables & $\begin{array}{l}\text { Seller and purchaser: } \\
-\quad \text { Tax uncertainty relating to the deductibility of irrecoverable debt. } \\
-\quad \text { Tax uncertainty relating to the Value Added Tax treatment of trade receivables and irrecoverable debt. }\end{array}$ \\
\hline \multicolumn{2}{|l|}{ Non-current liabilities } \\
\hline $\begin{array}{l}\text { Long-term } \\
\text { provisions }\end{array}$ & $\begin{array}{l}\text { Seller: } \\
\text { - Tax uncertainty relating to the deductibility of conditional liabilities assumed by the purchaser. } \\
\text { - } \quad \text { Tax uncertainty relating to the recoupment of expenses assumed by the purchaser. } \\
\text { Purchaser: } \\
\text { - Tax uncertainty relating to the deductibility of expenses associated with conditional liabilities upon } \\
\text { subsequent settlement. } \\
\text { - Uncertainty relating to the tax treatment of the 'reduction' in the purchase consideration and subsequent } \\
\text { settlement of the obligation at a reduced value. }\end{array}$ \\
\hline \multicolumn{2}{|l|}{ Current liabilities } \\
\hline $\begin{array}{l}\text { Trade and other } \\
\text { payables }\end{array}$ & $\begin{array}{l}\text { Seller and purchaser: } \\
-\quad \text { Uncertainty relating to the Value Added Tax implications associated with the sale of a business. }\end{array}$ \\
\hline Current tax payable & $\begin{array}{l}\text { Seller: } \\
\text { - Tax uncertainty relating to the inclusion of adjustments in the purchase consideration in gross income. } \\
\text { Purchaser: } \\
\text { - } \quad \text { Tax uncertainty relating to the deductibility of adjustments to the purchase consideration. } \\
\text { - } \quad \text { Tax uncertainty relating to the deductibility of finance cost incurred in financing the sale of a business. } \\
\text { - } \quad \text { Uncertainty relating to the tax treatment of costs incurred as a consequence of the sale of a business. } \\
\text { - } \quad \text { Uncertainty relating to the Value Added Tax treatment of costs incurred as a consequence of the sale of } \\
\text { a business. } \\
\text { Seller and purchaser: } \\
\text { - Discretionary allocation of the purchase consideration by the South African Revenue Service resulting in } \\
\text { an uncertain and tax inefficient position. } \\
\text { Uncertainty relating to which of the contracting parties is responsible for tax between the effective date } \\
\text { and the completion date. } \\
\text { Tax uncertainty relating to the existence of the section } 24 \mathrm{C} \text { allowance for the contracting parties. }\end{array}$ \\
\hline $\begin{array}{l}\text { Short-term } \\
\text { provisions }\end{array}$ & rtainties are similar to those of long-term provisions. \\
\hline
\end{tabular}

The risk identification tool will enable the contracting parties to adopt a proactive risk assessment process with the ultimate goal of planning the transaction in a tax efficient manner and successfully navigating the tax minefield involved in the sale of a business. 


\section{AUTHOR INFORMATION}

Luan Fouche, Bcom (Hons), Chartered Accountant (SA), Mcom Taxation student, Department of Taxation, University of Pretoria, South Africa. E-mail: luan.fouche@kpmg.co.za (Corresponding author)

Madeleine Stiglingh, Bcom (Hons), Mcom Taxation, Dcom Taxation, Chartered Accountant (SA), Professor and Head of Department of Taxation, University of Pretoria, South Africa. E-mail: Madeleine.Stiglingh@up.ac.za

\section{REFERENCES}

1. Ackermans $v$ CSARS (441/09) [2010] ZASCA 131

2. Australian Taxation Office (ATO). (2006). Large Business tax compliance. Retrieved from: www.ato.gov.au/content/downloads/77898 N8675-08-2006_w.pdf [Accessed: 2012-06-28].

3. Botha, A.J.J. (2004). Mergers And Acquisitions: Analysing The Tax Implications For Multinational Corporations. Unpublished MCom thesis. Pretoria: University of Pretoria.

4. Botha, J. (2012). Verbal communication with the Author on 27 June. Johannesburg. (Transcript/notes in possession of the author).

5. $\quad$ CIR v Niko 1940 AD 416, 11 SATC 124

6. COSO. (2010). COSO's 2010 Report on ERM. [Online] available at http://www.coso.org/documents/ COSOSurveyReportFULL-Web-R6FINALforWEBPOSTING111710.pdf [Accessed: 2012-06-28].

7. COSO. (1992). Internal control: Integrated framework. Retrieved from: http://www.coso.org/documents/Internal\%20Control-Integrated\%20Framework.pdf [Accessed: 2012-0628].

8. Davids, E. \& Yuill, D. (2010). Mergers \& Acquisitions in 61 jurisdictions worldwide: South Africa. [Online] Available from http://www.bowman.co.za/LawArticles/Publications/GettingTheDealThroughMergersandAcquisitions-SouthAfrica.pdf Downloaded: 2012-03-23].

9. $\quad$ Elgood, T., Paroissien, I., \& Quimby, L. (2006). Tax risk management guide. Retrieved from: http://www.pwc.com/gx/en/tax-management-strategy/tax-risk-management-guide.jhtml [Accessed: 201206-12].

10. Engel, K. (2012). Verbal communication with the author on 14 June. Pretoria. (Transcript/notes in possession of the author).

11. Erasmus, D.N. (2007). 7 habitual tax mistakes: A tax risk management handbook. Durban: LexisNexis.

12. Ernst \& Young. (2011). Global M\&A tax survey and trends: The growing role of the tax director. Retrieved from: http://www.ey.com/GL/en/Services/Tax/Global-M-A-tax-survey-and-trends--the-growing-role-of-the -tax-director [Accessed: 2012-03-23].

13. Eveready $v$ The Commissioner for the SARS (195/11) [2012] ZASCA 36

14. IASC. (2009). A Guide through International Financial Reporting Standards (IFRSs) 2009. London: IASC Foundation Publications Department.

15. IRC $v$ Ramsay 20 TC 79

16. ITC 183972 SATC 61

17. KPMG. (2006). KPMG mergers and acquisition survey. KPMG: USA. Retrieved from: http://www.kpmgtaxwatch.com/docs/2006_MA_Outlook_Survey_Press.pdf [Accessed: 2009-06-17].

18. Kruger, D. (2010). The Sale Of A Business: The Assumption Of Liabilities In Part Settlement Of The Purchase Price And The VAT Implications Where The Corporate Rules Apply. Business Tax \& Company Law Quarterly, 1(4) 17-26.

19. Lamb, M., Lymer, A., Freedman, J. \& James, S. (2005). Taxation: An interdisciplinary approach to research. New York: Oxford University Press.

20. Louw, C. (2012). Verbal communication with the author on 19 June. Pretoria. (Transcript/notes in possession of the author).

21. Molyneux, G. \& Du Plessis, I. (2007). Tax Risk Management: A Rapid Rise Up The Board Agenda. Accountancy SA, 706. Retrieved from: http://www.accountancysa.org.za/ resources/showitemarticle.asp? articleId =1056\&Issue=706 [Accessed: 2012-03-23].

22. Nel, P. (2012). Verbal communication with the author on 11 June. Pretoria. (Transcript/notes in possession of the author).

(C) 2013 The Clute Institute http://www.cluteinstitute.com/ 
23. OECD. (2009). Forum on Tax Administration. Information Note General Administrative Principles: Corporate governance and tax risk management. Retrieved from http://www.oecd.org/dataoecd/37/19/43239887.pdf [Accessed: 2012-06-28].

24. Olivier, L. (2007). Tax Implications Of The Sale Of A Business. The South African Law Journal, 124(3) 600-617.

25. PriceWaterhouseCoopers. (2011). PwC-Practical guide to IFRS: Determining what's a business under IFRS 3 (2008). Retrieved from: http://www.pwc.co.za/en_ZA/za/assets/pdf/PG16_Business_IFRS3.pdf [Accessed: 2012-06-18].

26. Rudnicki, M. (2012). Verbal communication with the author on 21 June. Johannesburg. (Transcript/notes in possession of the author).

27. Rudnicki, M. (2010). The Salient Features Of A Sale-Of-Business Transaction. Business Tax \& Company Law Quarterly, 1(1) 24-30.

28. $\quad$ SIR v Kempton Furnishers (Pty) Ltd 1974(3) SA 36(A)

29. Stiglingh, M. \& Venter, J.M.P. (1999). Die Belastinghantering Van Voorsienings Met Die Verkoop Van 'N Besigheid As 'N Lopende Saak. Meditari: 237-256.

30. Thomson Reuters. (2011). Mergers \& acquisitions review: Financial advisors - first 9 months of 2011. Retrieved from: https://www.thomsonone.com [Accessed on 2012-03-24].

31. Wilcocks, J. (2012). Inventory. In Stiglingh, M (ed.) SILKE: South African income tax. Durban: Lexis Nexis.

32. Wingard, H.C., Von Well, R., Pretorius, D., Ferreira, P.H., Badenhorst, W.M. \& Van der Merwe, D. (2012). GAAP handbook: Financial accounting and reporting practice. Durban: Lexis Nexis.

33. Wry, C.A. (2011). Tax considerations in buying or selling a business. Retrieved from: http://www.mbbp.com/resources/tax/buying_selling.html [Downloaded: 2012-03-23]. 